\title{
Evaluation of maize-yam peel meal based diets supplemented with exogenous cocktail enzymes on growth performance, nutrient digestibility and metabolisable energy in finisher broiler chickens.
}

\author{
* ${ }^{1}$ Oguntoye, M. A., ${ }^{2}$ Maikano, Y., ${ }^{1}$ Samuel, T., ${ }^{1}$ Usman, I. and ${ }^{1}$ Ahmed, A. \\ ${ }^{\prime}$ Dept of Animal Science, Taraba State University Jalingo. \\ ${ }^{2}$ Dept of Animal Production Technology, College of Agriculture Jalingo.
}

Abstract Corresponding author's email: ingenuityma@gmail.com

This study was conducted to investigate the effect of maize and yam peels meal based diets with and without enzyme supplementation on the growth performance and nutrient digestibility of broiler chickens at finisher phase. One hundred and eighty (180), one day-old broiler chicks were fed six diets in two groups. The experiment was arranged in a $2 \times 3$ factorial experimental layout of two levels of enzyme $(0 \mathrm{~g} / 100 \mathrm{~kg}$ diet and $50 \mathrm{~g} / 100 \mathrm{~kg}$ diet $)$ and three levels of yam peels inclusion $(0 \mathrm{~kg}, 15 \mathrm{~kg}$ and $30 \mathrm{~kg})$. Each treatment was replicated 3 times consisting of 10 chicks per replicate. The experiment lasted 4 weeks. Main effect of graded levels of yam peel meal and enzymes supplementation on growth performance of starter broiler chickens showed significant $(P \square 0.05)$ influence on final weight, total weight, total weight grain and daily weight grain. Birds fed 0\% YPM recorded higher statistical value of $2549.00 \mathrm{~g}$ for final weight. Interaction effect of YPM and enzyme showed significant $(<0.05)$ effect on growth performance of finisher broiler chickens. Final weight, total weight gain and daily weight gain were significantly $(<0.05)$ influenced by interaction of YPM and enzyme. Birds fed control diet $\left(T_{1}\right)$ recorded higher significant $(P<0.05)$ values for final weight of comparative level. Least value of $2220.00 \mathrm{~g}$ was recorded for final weight in the birds fed $15 \%$ YPM without enzyme $\left(T_{2}\right)$. Varying levels of YPM as a partial replacement for maize had no significant $(P>0.05)$ effect on nutrient digestibility. Higher values were recorded for birds fed $0 \%$ inclusion level of YPM across the parameter determined with the exception of ether extract and ash. Inclusion of YPM with enzyme supplementation had significant $(P<0.05)$ interaction effects on percentage dry matter digestibility, crude protein digestibility and crude fibre digestibility. Dry matter digestibility decreased with increased level of YPM with or without enzyme. Inclusion of yam peels meal up to $30 \%$ level of replacement for maize with or without enzyme supplementation could be recommended for appreciable nutrient digestibility and improved growth performance of finisher broiler chickens.

Keywords: Yam peel, enzyme, performance, nutrient digestibility, broiler chickens.

\section{Introduction}

The main problem of poultry in sub-saharan countries today is the cost of feed ingredients. This challenge has reduced the rate of expansion of poultry industry and has added to low level of animal protein intake of the populace. Attempts to reduce the high cost of feeds and therefore high cost of production have brought about feed formulation from available and cheap unconventional feedstuffs. There is the need to harness the potential of agroindustrial by-products and other unconventional feed sources (Edache et al., 2005). High price of maize has forced farmers to seek yam peel as an alternative to maize in livestock feeding. Several scientists in Nigeria have shown that yam peel can be used in diet for livestock (Akinmutimi and Onen 2008; Lawal et al., 2017; Tewe, 1992).

Some agro by-products have been used in the diets of broiler chicks, including wheat offal and citrus pulp in broiler chicken diets (Faniyi, 2002), palm kernel cake to replace 


\section{Evaluation of maize-yam peel meal based diets}

soya bean meal as a protein source in broiler chicken production (Oruseibio and Smile, 2002) and the results were encouraging. Yam peels are basic wastes or by-products when yam is peeled during processing for cooking and other purposes. Yam peels are however, fed to animals such as goats and sheep and largely sourced from yam processing centres, or kitchens. Yam peels may be fed directly soon after peeling, or sun dried for $4-7$ days depending on ambient temperature, to dehydrate it thereby preventing microbial fermentation of the product or fungal infestation. Constraints on the use of by-products and crop residues according to $\mathrm{El} \mathrm{Hag}$ and Kurdi (1986) include: bulkiness, location in areas with lower animal population density, poor nutritive value and unsuitability for direct animal use. In Nigeria today, the issue of the bulkiness and location in areas far from those where the materials are needed has been partially solved by the development of a good network of roads and the opening up of the rural areas for development

As regards the poor nutritive value and nonsuitability for immediate animal use, research results have shown that physical (grinding and pelleting) treatments improve the nutritive value and intake and hence the response of animals to some of agro by-products. El Hag and Kurdi (1986) concluded that physical treatment was more useful in improving the nutritive value of agro by-products and was also economically more feasible than the chemical treatment. Agro-industrial byproducts and crop residues represent a vast animal feed resource, which is as yet largely unexploited. Yam belong to the Genius; Discoreae, species; (D. rotundata, D. alata). Yam peels are wastes or by- product of processing when the tubers are being prepared by human. Yam peel is however, fed to animals such as goats and sheep and largely sourced from yam processing centers or yam sellers. Ekenyem and Madubuike (2006); Faniyi (2002) had rated feeds as constituting $70-80 \%$ of the cost of poultry production, of which maize constitutes major costs. There is therefore urgent need to explore cheaper alternative feed resources. Yam peel is readily available in all parts of Nigeria with little or no cost. One of the challenges of yam peel meal (YPM) is present of anti-nutritional factors such as: Oxalate, tannin, phytate and saponin (Akinmutimi and Onen 2008). Sun drying and enzyme treatments are some of methods adopted for treating antinutritional factors in feed ingredients. This feeding trial is aimed at evaluating the nutritional value of maize-yam peels based diets supplemented with exogenous xylanase, amylase and protease multienzyme on growth performance, nutrient digestibility and metabolizable energy in finisher broiler chickens with a view to ascertaining its potentials for reducing the cost of chicken production.

\section{Materials and methods Experimental diets}

A total of six isonitrogenous diets were formulated for broiler chickens to meet NRC (1994) minimum nutrient requirement. The diets were formulated such that maize was replaced by yam peels on weight to weight basis. The replacement is in order of 0,15 and $30 \mathrm{~kg}$ of yam peels meal (YPM) with 0 and $50 \mathrm{~g} / \mathrm{kg}$ levels of enzyme supplementation. Dietary treatments consist: Maize based diet contained 0kg YPM without enzyme (T1), Maize based diet contained $15 \mathrm{~kg}$ YPM without enzyme (T2), Maize based diet contained $30 \mathrm{~kg}$ YPM without enzyme (T3), Maize based diet contained $0 \mathrm{~kg}$ YPM with enzyme (T4), Maize based diet contained $15 \mathrm{~kg}$ YPM with enzyme (T5) and Maize based diet contained $30 \mathrm{~kg}$ YPM with enzyme (T6), respectively as presented in Table 1. 
Oguntoye, Maikano, Samuel, Usman and Ahmed

Table 1: Percentage composition of broiler finisher diets (5-8 weeks)

\begin{tabular}{|c|c|c|c|c|c|c|}
\hline \multirow{3}{*}{$\begin{array}{l}\text { Enzyme } \\
\text { YPM levels (kg) }\end{array}$} & \multicolumn{3}{|c|}{$0 \mathrm{~g} / \mathrm{kg}$} & \multicolumn{3}{|c|}{$50 \mathrm{~g} / \mathrm{kg}$} \\
\hline & $\mathbf{0}$ & 15 & 30 & $\mathbf{0}$ & 15 & 30 \\
\hline & T1 & $\mathbf{T} 2$ & T3 & T4 & T5 & T6 \\
\hline \multicolumn{7}{|l|}{ Ingredients: } \\
\hline Maize & 60.00 & 45.00 & 30.00 & 60.00 & 45.00 & 30.00 \\
\hline YPM & 0.00 & 15.00 & 30.00 & 0.00 & 15.00 & 30.00 \\
\hline Palm oil & 2.00 & 2.50 & 2.50 & 2.00 & 2.50 & 2.50 \\
\hline Soya bean meal & 14.20 & 14.20 & 14.20 & 14.20 & 14.20 & 14.20 \\
\hline Groundnut cake & 12.40 & 12.40 & 12.40 & 12.40 & 12.40 & 12.40 \\
\hline Fish meal & 2.00 & 2.00 & 2.00 & 2.00 & 2.00 & 2.00 \\
\hline Rice offal & 4.50 & 4.50 & 4.50 & 4.50 & 4.50 & 4.50 \\
\hline Bone meal & 2.00 & 2.00 & 2.00 & 2.00 & 2.00 & 2.00 \\
\hline Lime stone & 1.50 & 1.50 & 1.50 & 1.50 & 1.50 & 1.50 \\
\hline DL-Methionine & 0.30 & 0.30 & 0.30 & 0.30 & 0.30 & 0.30 \\
\hline L-Lysine & 0.10 & 0.10 & 0.10 & 0.10 & 0.10 & 0.10 \\
\hline Salt & 0.25 & 0.25 & 0.25 & 0.25 & 0.25 & 0.25 \\
\hline *Premix & 0.25 & 0.25 & 0.25 & 0.25 & 0.25 & 0.25 \\
\hline Total & 100.00 & 100.00 & 100.00 & 100.00 & 100.00 & 100.00 \\
\hline \multicolumn{7}{|l|}{ Supplementation } \\
\hline Enzymes $(50 \mathrm{~g} / 100 \mathrm{~kg})$ & - & - & - & + & + & + \\
\hline \multicolumn{7}{|l|}{ Calculated analysis: } \\
\hline $\mathrm{ME}(\mathrm{kcal} / \mathrm{kg})$ & 3019.15 & 2989.61 & 2928.11 & 3019.15 & 2989.61 & 2928.11 \\
\hline Crude protein $(\%)$ & 19.41 & 19.24 & 19.11 & 19.41 & 19.24 & 19.11 \\
\hline Crude fibre $(\%)$ & 3.17 & 4.07 & 5.02 & 3.17 & 4.07 & 5.02 \\
\hline Ether extract $(\%)$ & 4.01 & 3.52 & 3.07 & 4.01 & 3.52 & 3.07 \\
\hline $\mathrm{Ca}(\%)$ & 1.19 & 1.19 & 1.19 & 1.19 & 1.19 & 1.19 \\
\hline $\mathrm{P}(\%)$ & 0.43 & 0.42 & 0.41 & 0.43 & 0.42 & 0.41 \\
\hline L-Lysine (\%) & 0.92 & 0.88 & 0.85 & 0.92 & 0.88 & 0.85 \\
\hline DL-Methionine (\%) & 0.59 & 0.56 & 0.53 & 0.59 & 0.56 & 0.53 \\
\hline
\end{tabular}

Table 2: Proximate composition of yam-peels meal

\begin{tabular}{lc}
\hline Constituents & Percentage (\% DM) \\
\hline Dry matter & 87.40 \\
Crude protein & 4.38 \\
Crude fibre & 9.80 \\
Ether extract & 4.43 \\
Ash & 6.50 \\
Nitrogen free extract & 74.89 \\
Energy (kcal/kg ME) & 3,179 \\
\hline
\end{tabular}

Design and management of experimental birds

A total number of 180, one day-old unsexed broiler chicks of commercial strain (Anak 2000) were purchased from a reputable hatchery. The chicks were weighed and allotted to six dietary treatment groups of three replicates each in a $2 \times 3$ factorial arrangement of a Completely Randomized Design. Each replicate consist of 10 chicks and 30 birds per treatment group. The experiment was arranged in a $2 \times 3$ factorial experimental layout of two levels of enzyme $(0 \mathrm{~g} / 100 \mathrm{~kg}$ diet and $50 \mathrm{~g} / 100 \mathrm{~kg}$ diet $)$ and three levels of yam peels inclusion $(0 \mathrm{~kg}, 15 \mathrm{~kg}$ and $30 \mathrm{~kg})$. The birds were brooded for two weeks. Birds were reared on deep litter housing system for four weeks (0-4 weeks). Routine vaccinations and medications were strictly followed and feed and water were provided ad libitum.

\section{Data collection}

\section{Growth performance characteristics}

The initial weights of the birds were taken on arrival. The live weights of the birds as well as the feed consumption of each 


\section{Evaluation of maize-yam peel meal based diets}

replicate were measured weekly. Feed conversion ratio for each replicate was determined by dividing the feed intake by the weight gain.

Feed intake/bird $(g)=$ Quantity of feed fed Quantity offeed left over

Number of bird $x 28$ day

Daily weight gain $(g)=\underline{\text { Final live weight }-}$ Initial weight

Number of bird $x 28$

Feed conversion ratio $=$ Quantity of feed consumed

\section{Weightgain}

\section{Nutrient digestibility}

Metabolic trial was conducted at the $8^{\text {th }}$ week of the study. A bird per replicate was randomly selected and housed separately in appropriate metabolic cage fitted with feeder and drinker. The birds were allowed to acclimatize for two days before the commencement of 4 days feeding and excreta collection. A known weight of feed was given and excreta collected per bird per day were sun dried and use for analyses. Proximate composition of the feed and dried excreta were analyzed for dry matter, crude protein, ether extract, crude fibre and ash using standard method of AOAC (2000).

\section{Energy metabolizability}

A bird per replicate was randomly selected and housed separately in appropriate metabolic cage fitted with drinker. Birds were starved of diets, given unrestricted access to clean water for 24 hours during which the excreta voided was discarded. After the expiration of 24 hours starvation, each bird were dosed with glucose solution $(30 \mathrm{~g}$ of glucose $/ 50 \mathrm{ml}$ of warm water at $40^{\circ} \mathrm{C}$ ) to reduce stress and deprived of feed for another 24 hours making a total of $48 \mathrm{~h}$ starvation period. Total excreta collection per bird during the last (24 hour) phase of feed starvation was used for the estimation of endogenous losses. Gross energy of excreta samples (from fed and starved birds) was estimated using the adiabatic bomb calorimeter (Model 1261; Parr Instrument Co., Moline, IL, US). The apparent metabolizable energy (AME), nitrogen corrected AME (AMEn), true metabolizable energy (TME), and nitrogen corrected TME (TMEn) were computed using the equations as described by Sibbald (1989).

$A M E / g$ of the feed $=[(F i X G E f)-(E X$ $\mathrm{GEe})] / \mathrm{Fi}$

Where: Fi is the feed intake ( $\mathrm{g}$ on dry matter basis), $\mathrm{E}$ is quantity of excreta output ( $\mathrm{g}$ on dry matter basis),

GEf is gross energy $\mathrm{MJ} / \mathrm{kg}$ of the feed and $\mathrm{GEe}$ is gross energy $\mathrm{MJ} / \mathrm{kg}$ of the excreta. $A M E n / g$ of the feed $=\{[(\mathrm{Fi}$

$X G E f)-(E x G E e)]-(N R \times 36.5)\} / F i$

Where: nitrogen retention $(\mathrm{NR})=(\mathrm{Fi} \times \mathrm{Nf})$ $-(\mathrm{E} \times \mathrm{Ne}), \mathrm{Nf}$ is nitrogen content $(\mathrm{g} / \mathrm{kg})$ of the feed, Ne is nitrogen content $(\mathrm{g} / \mathrm{kg})$ of the excreta.

$T M E / g$ of the feed $=\{[(F i x G E f)-(E x$ $\mathrm{GEe})]+(\mathrm{FEm}+\mathrm{UEe})\} / F i$

Where: FEm is metabolic faecal energy (KJ) from endogenous loss and UEe is endogenous urinary energy $(\mathrm{KJ})$ (This is assumed to be zero in birds).

$T M E / g$ of the feed $=\{[(F i x G E f)-(E x$ GEe $)]-(N R x K)\}+[(F E m+U E e)+(N R o x$ 36.5]\}/Fi

Where: NR and NRo are estimate of nitrogen retention for fed and starved birds respectively.

\section{Statistical analysis}

Data were subjected to analysis of variance using the SPSS software (2012). Where analysis of variance indicated significant treatment effects, means were compared using Duncan's New Multiple Range Test (DNMRT) (SPSS, 2012).

\section{Results and discussion}

The main effect of varying levels of yam peel meal (YPM) and enzyme 


\section{Oguntoye, Maikano, Samuel, Usman and Ahmed}

supplementation on growth performance of finisher broiler chickens is summarized in Table 3. Graded levels of YPM had significant $(\mathrm{P}<0.05)$ effect on final weight, total weight gain and daily weight gain. This observation was at variance with report of Akinmutimin and Onen (2008) that inclusion of graded levels of YPM had no significant $(\mathrm{P}>20.05)$ effect on all parameters measured. Birds fed 0\% YPM recorded higher final weight of $2548.50 \mathrm{~g}$ while. Least values of 2309.00 and $2332.00 \mathrm{~g}$ were recorded for birds fed diets containing $15 \%$ and 30\% YPM inclusion, respectively. Similar trend was observed for total weight gain and daily weight gain. This observation is in contrast to the observation of Lawal et al. (2017) that inclusion of YPM at $30 \%$ recorded highest value for final weight and weight gain in broiler chickens when compared to lower levels of inclusion in other dietary treatments. Reduction in growth performance recorded with increased level of YPM could be attributed to fibrous content of the diet as there is a negative correlation between energy content and fibrous content of the feed (Jasen and Cawe, 1985). Similarly, Yunusa et al. (2014) attributed decreased growth performance of broiler chicken with increased YPM to high fibre content which could accelerate the transit of ingested feed through the gastro-intestinal tract of the birds and consequently limited time for proper digestion and absorption of nutrients. Findings in this study corroborated the report in literature (Ezieshi and Olomu, 2011) on decreased value in final weight and weight gain with increased level of YPM as a replacement for maize.

Main effect of enzyme supplementation had no significant $(\mathrm{P}>0.05)$ effect on all parameters measured. Though elevated numerical values were recorded with enzyme supplementation across all the parameters measured. This observation corroborated the report in literature (Aguibe et al., 2015) on higher numerical values for final weight and weight gain when birds were fed YPM supplemented with enzyme. Result in Table 4 showed interaction effect of YPM and enzyme on growth performance of finisher broiler chickens. Final weight, total weight gain and daily weight gain were significantly $(<0.05)$ influenced by interaction of YPM and enzyme. Birds fed control diet $\left(\mathrm{T}_{1}\right)$ recorded higher significant $(\mathrm{P}<0.05)$ values for final weight at comparative level. Least value of $2220.00 \mathrm{~g}$ was recorded for final weight in birds fed 15\% YPM without enzyme $\left(\mathrm{T}_{2}\right)$. Similar trend was observed for total weight gain and daily weight gain in which birds fed control diet recorded higher values and least values for birds fed $\mathrm{T}_{2}$. Observation in this study disagreed with reports in literature (Apodiete et al., 2006; Mojtaba et al., 2014) on higher weight gain in birds fed enzyme supplemented diet in comparison to birds fed diet without enzyme.

Table 3: Main effects of yam peels meal and enzyme supplementation on growth performance of finisher broiler chickens ( 5 - 8 weeks)

\begin{tabular}{|c|c|c|c|c|c|c|c|}
\hline \multirow[b]{2}{*}{ Parameter } & \multicolumn{2}{|c|}{ Yam Peels Meal } & \multirow[b]{2}{*}{$30 \%$} & \multirow[b]{2}{*}{ SEM } & \multicolumn{2}{|c|}{ Enzyme } & \multirow[b]{2}{*}{ SEM } \\
\hline & $0 \%$ & $15 \%$ & & & $0 \mathrm{~g}$ & $50 \mathrm{~g}$ & \\
\hline Initial weight (g) & 957.17 & 957.50 & 957.33 & 0.67 & 957.22 & 957.44 & 0.55 \\
\hline Final weight (g) & $2548.50^{\mathrm{a}}$ & $2309.00^{\mathrm{b}}$ & $2332.00^{\mathrm{b}}$ & 66.86 & 2355.00 & 2437.00 & 54.59 \\
\hline Weight gain $(\mathrm{g} / \mathrm{bird})$ & $1592.00^{\mathrm{a}}$ & $1351.00^{\mathrm{b}}$ & $1375.00^{\mathrm{b}}$ & 66.75 & 1398.00 & 1480.00 & 54.51 \\
\hline Daily weight gain (g/bird) & $56.84^{\mathrm{a}}$ & $48.24^{\mathrm{b}}$ & $49.10^{\mathrm{b}}$ & 2.38 & 49.93 & 52.85 & 1.95 \\
\hline Feed intake (g/bird) & 3334.00 & 3990.00 & 3986.00 & 380.01 & 3549.00 & 3992.00 & 310.27 \\
\hline Daily feed intake (g/bird) & 142.57 & 143.79 & 142.56 & 1.21 & 142.38 & 142.55 & 0.43 \\
\hline Feed conversion ratio & 2.53 & 2.98 & 2.94 & 0.14 & 2.92 & 2.71 & 0.12 \\
\hline
\end{tabular}

${ }^{\mathrm{ab}}$ Mean on the same row having different superscripts were significantly $(\mathrm{P}<0.05)$ different. 


\section{Evaluation of maize-yam peel meal based diets}

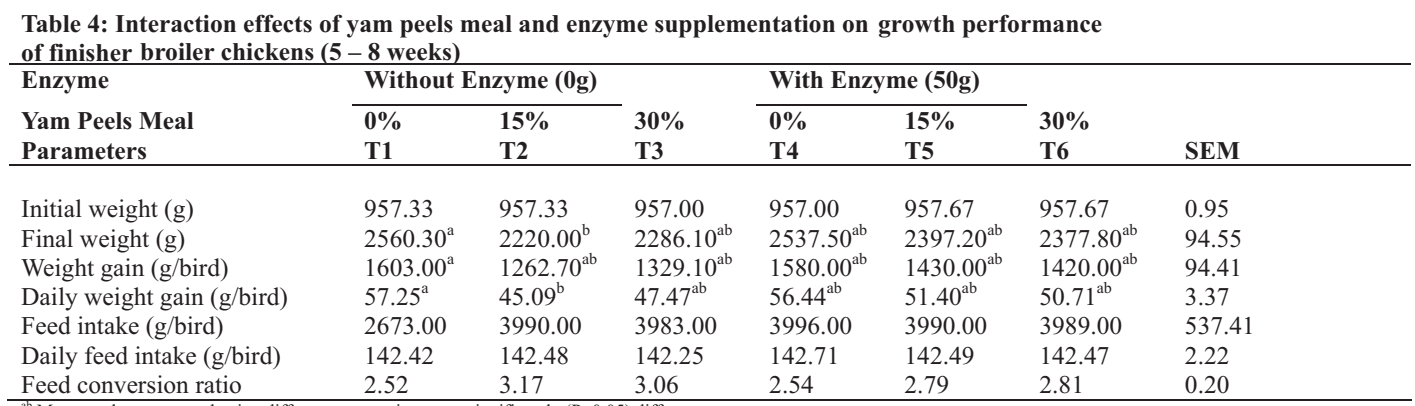

Main effect of yam peel meal (YPM) and enzyme supplementation Nutrient digestibility and energy metabolizability in finisher broiler chickens showing the is presented in Table 5. Varying levels of YPM as a partial replacement for maize showed no significant $(\mathrm{P}>0.05)$ influence on all the parameters determined. Though not significant $(\mathrm{P}>0.05)$, elevated values were recorded for birds fed $0 \%$ inclusion level of YPM across the parameter determined with the exception of ether extract and ash. This observed numerical decrease with increasing level of YPM could be attributed to the effect of partial replacement of highly digestible source of carbohydrate, maize by yam peel meal which is of low digestibility. The YPM inclusion had no significant $(\mathrm{P}>0.05)$ effect on energy metabolisability. Decreased numerical values were recorded for energy metabolizability. The AMEn, TME and TMEn decreased numerically with increased level of YPM. The relative reduced metabolizable energy obtained in this study could be attributed to fibrous content of the diet since birds lack endogenous enzyme to digest fibrous feed (Bedford and Classen, 1992).

Main effect of enzyme supplementation showed no significant $(\mathrm{P}>0.05)$ effect on parameters determined. Though not significant $(\mathrm{P}>0.05)$, elevated values were recorded for dry matter, crude fiber and TME in the birds fed enzyme supplemented diet. This observation could be attributed to ability of exogenous enzyme to increase crude fibre digestibility. Enzyme act on cellulose, glucoxylans and arabinoxylans thereby reducing the dietary fibre content and consequently increase the energy content (Aya et al., 2013).

Interaction effect of yam peel meal with enzyme supplementation on nutrient digestibility and energy metabolizability of finisher broiler chicken is presented in Table 6. Significant $(\mathrm{P}<0.05)$ interaction effects were observed for percentage dry matter digestibility, crude protein digestibility and crude fibre digestibility. This observation corroborated the report in literature (Ezieshi and Olomu, 2011) who reported significant $(p<0.05)$ effect on dry matter, crude protein and crude fibre digestibility when broiler chickens were fed diet with varying levels of yam peel meal as a partial replacement for maize. In similar trend, Aguibe et al. (2015) reported significant $(p<0.05)$ influence of YPM on crude protein, crude fibre, ether extract and ash digestibility. Dry matter digestibility decreased with increased level of YPM with or without enzyme. Presence of fibre could speed up the transit time of ingesta through the gastrointestinal tract of the birds thereby leaving limited time for proper digestion and intensive absorption of nutrient (Yunusa et al., 2014). High significant $(\mathrm{P}<0.05)$ values were recorded for dry matter digestibility in the birds fed enzyme supplemented diet at comparative level to 


\section{Oguntoye, Maikano, Samuel, Usman and Ahmed}

birds on diet without enzyme. Birds fed $0 \%$ YPM with enzyme supplementation (T4) recorded highest value $76.00 \%$ for dry matter digestibility.

Improved dry matter digestibility with enzyme supplementation as observed in this current study might be due to better utilization of nutrient from non-starch polysaccharides (NSP) as influenced by the exogenous enzyme. Enzyme supplementation aid disruption of plant wall thereby enhancing nutrient availability through solubilisation and disappearance of fibre (Olukosi et al., 2015). Crude protein digestibility decreased linearly with increased level of YPM with or without enzyme supplementation. This observation supported report in literature (Iyayi and Davies, 2005) that fibrous feeds decreased digestibility of crude protein. This could be as a result of reduction in transit time of the ingesta due to fibrous nature of YPM which consequently caused limited time for proper digestion and absorption of nutrient (Yunusa et al., 2014).

Similar trend was observed for crude fibre digestibility which decreased with increased level of YPM. Higher significant value $67.21 \%$ was recorded for crude fibre digestibility in the birds fed enzyme supplemented diets T4 at comparative level to birds fed diets without enzyme. This corroborated the findings of Soltan (2009) and Ojewola et al. (2003) who reported improved fibrous digestibility in diet with exogenous enzyme supplementation. Exogenous enzyme supplementation improves digestibility of fibrous agricultural products (Rotter et al., 1990; Viveros et al., 2000).

Though not significant $(\mathrm{p}>0.05)$, values recorded for energy metabolizability decreased with YPM inclusion at comparative level to birds fed diets with $0 \%$ YPM. Insignificant relative reduction in metabolizable energy observed in this study could be attributed to presence of some deleterious factors contained in yam peel which limits its utilization. Yam peel was reported to contain tannin bound with fibre which had potential to inhibit digestive enzyme and reduce nutrient digestibility (Mariscal-Landin et al., 2004). Oduguwa et al. (2007) reported that indigestible fibre increased ileal viscosity and depressed nutrient digestibility. Birds fed enzyme supplemented diet (T4) showed high nonsignificant $(p>0.05)$ numerical values for parameters determined for energy metabolizability. Previous study showed significant improvement in energy metabolizability of feed ingredients followed enzyme supplementation (Adeola and Bedford, 2004; Meng and Slominski, 2005).

Table 5: Main effect of yam peels meal and enzyme supplementation on nutrient digestibility and energy metabolizability of finisher broiler chickens ( 8 weeks)

\begin{tabular}{lccccccc}
\hline & \multicolumn{3}{c}{ Yam Peels Meal } & & & \multicolumn{3}{c}{ Enzyme } \\
\cline { 2 - 3 } \cline { 6 - 7 } Parameter & $\mathbf{0 \%}$ & $\mathbf{1 5} \%$ & $\mathbf{3 0} \%$ & SEM & $\mathbf{0 g}$ & $\mathbf{5 0 g}$ & SEM \\
\hline Dry Matter & 75.25 & 71.25 & 71.0 & 0.612 & 71.66 & 73.33 & 0.50 \\
Crude Protein & 70.98 & 69.04 & 68.00 & 0.193 & 69.60 & 69.08 & 0.15 \\
Ether Extract & 72.53 & 73.00 & 73.75 & 0.447 & 73.52 & 72.66 & 0.36 \\
Crude Fibre & 66.47 & 62.77 & 62.16 & 0.939 & 63.26 & 64.33 & 0.76 \\
Ash & 59.99 & 59.88 & 61.36 & 0.428 & 60.32 & 60.50 & 0.34 \\
AME & 13.50 & 12.28 & 12.33 & 0.336 & 12.64 & 12.84 & 0.27 \\
AMEn & 13.32 & 12.28 & 12.11 & 0.335 & 12.43 & 12.71 & 0.27 \\
TME & 13.71 & 12.75 & 12.52 & 0.035 & 12.92 & 13.06 & 0.29 \\
TMEn & 13.37 & 12.16 & 11.99 & 0.357 & 12.44 & 12.58 & 0.29 \\
\hline
\end{tabular}




\section{Evaluation of maize-yam peel meal based diets}

Table 6: Interaction effects of yam peels meal and enzyme supplementation on nutrient digestibility and energy metabolizability of finisher broiler chickens ( 8 weeks)

\begin{tabular}{|c|c|c|c|c|c|c|c|}
\hline \multirow{3}{*}{$\begin{array}{l}\text { Enzymes }(\mathrm{kg}) \\
\text { Yam peel meal (\%) } \\
\text { Parameters }\end{array}$} & \multicolumn{3}{|c|}{ Without Enzyme (0g/100kg) } & \multicolumn{3}{|c|}{ With Enzyme (50g/100kg) } & \multirow[b]{3}{*}{ SEM } \\
\hline & $\mathbf{0}$ & 15 & 30 & $\mathbf{0}$ & 15 & 30 & \\
\hline & T1 & T2 & T3 & T4 & T5 & T6 & \\
\hline Dry Matter & $74.50^{\mathrm{ab}}$ & $70.50^{c}$ & $70.00^{c}$ & $76.00^{\mathrm{a}}$ & $72.00^{b}$ & $72.00^{b}$ & 0.86 \\
\hline Crude Protein & $72.07^{\mathrm{a}}$ & $68.97^{\mathrm{c}}$ & $67.76^{\mathrm{d}}$ & $69.90^{\mathrm{b}}$ & $69.11^{b c}$ & $68.25^{\mathrm{d}}$ & 0.27 \\
\hline Ether Extract & 72.57 & 73.50 & 74.50 & 72.50 & 72.50 & 73.00 & 0.63 \\
\hline Crude Fibre & $65.72^{\mathrm{a}}$ & $62.86^{\mathrm{abc}}$ & $61.21^{\mathrm{c}}$ & $67.21^{\mathrm{a}}$ & $62.68^{\mathrm{bc}}$ & $63.11^{\mathrm{abc}}$ & 1.33 \\
\hline Ash & 59.49 & 60.25 & 61.23 & 60.50 & 59.51 & 61.49 & 0.61 \\
\hline AME & 13.26 & 12.21 & 12.44 & 13.74 & 12.56 & 12.21 & 0.47 \\
\hline AMEn & 13.53 & 12.07 & 12.19 & 13.62 & 12.49 & 12.04 & 0.47 \\
\hline TME & 13.53 & 12.59 & 12.65 & 13.89 & 12.90 & 12.39 & 0.50 \\
\hline TMEn & 13.26 & 11.97 & 12.09 & 13.49 & 12.36 & 11.89 & 0.50 \\
\hline
\end{tabular}

\section{Conclusion}

This study revealed that Yam peel meal as a partial replacement for maize in the ration of finisher broiler chickens significantly affected growth performance. Inclusion of yam peels meal and enzyme as partial replacement for maize in the ration of finisher broiler chickens resulted in decreased dry matter digestibility with increased level of YPM with or without enzyme. Inclusion of yam peel meal up to $30 \%$ level of replacement for maize with or without enzyme supplementation could be fed to broiler chickens for improved growth performance.

\section{References}

A.O.A.C.1990. Association of Official and Analytical Chemists. Method of Analysis (15th edition). Published by the Association of Official and Analytical Chemists, Washington D.C.

Adeola, O. and Bedford, M. R. 2004. Exogenous dietary xylanase ameliorates viscosity-induced anti-nutritional effects in wheatbased diets for white pekin ducks (AnasPlatyrinchosdemesticus). British journal of nutrition. 92.8794.

Aguibe, P. C., Kehinde, A. S. and Iyayi,
E. A. 2015. Effect of enzyme $\left(\right.$ Maxigrain $\left.^{\circledR}\right)$ supplementation on performance characteristics and nutrient digestibility of growing Japanese quails (Cortunixcortunix japonica) fed diet containing yam peels meal. Nigeria Journal of Animal Science. 17(1): 65-74.

Akinmutimi, A. H. and Onen, G. E. 2008. The response of broiler finisher birds fed graded levels of yam peel meal in place of maize based diet. International Journal of Poultry Science, 7: 474-477.

Akpodiete, O. J., Eruvbetine, D. and Gagiyovwe, E. S. 2006. Effect of enzyme supplementation on palm kernel cake based diets on broiler chickens performance. Nigeria journal of poultry science. 4: 1-6.

Aya, V. E., Ajanwale, B. A., Iyayi, A. T. and Aremu, A. 2013. Performance and nutrient digestibility in broiler chicks as influenced by multienzyme addition to starter diets containing palm kernel meal. Biotechnology and Animal Husbandry, 29(1): 93-104.

Bedford, M. R. and Classen, H. L. 1992. Reduction of intestinal viscosity through manipulation of dietary rye and pentosanase concentration is 


\section{Oguntoye, Maikano, Samuel, Usman and Ahmed}

effected through changes in the carbohydrate composition of the intestinal aqueous phase and results in improved growth rate and food conversion efficiency of broilers chicks. Journal of nutrition. 122: 560-569.

Edache, J. A., Musa, U., Haruna, E. S., Esilinu, J. O., Jibrin, I., Okpala, E. J. and Dogo, I. G. 2005. Replacement value of guinea corn for maize in practical diets fed to quail chicks. Journal of Animal Research International. 2(2): 311313.

Ekeyem, B. U., Madubuike, F. N. and Dike. O. F. 2006. Effects of partial replacement of yam peel meal for maize on performance and carcass characteristics of finisher chickens. International Journal of Poultry Science, 5: 942-945.

El Hag, M. G. and Kurdi, O. I. 1986. Prospects of efficient utilization of agro-industrial by-products and crop residues for ruminant feeding in the Sudan, with emphasis on quantification, nutritional composition, constraints and research results. In. T.R. Preston and M.Y. Nuwanyakpa (eds), Towards optimal feeding of agricultural by-products to livestock in Africa. Proceedings of workshop held at Alexandria, Egypt, October 1985. ILCA, Addis Ababa. pp. 22 - 23.

Ezieshi, E. V. and Olomu, J. M. 2004. Comparative performance of broiler chickens fed varying levels of palm kernel cake and maize offal. Pakistan Journal of Nutrition, 3: 254-257.

Faniyi, G. F., 2002. Replacement of Wheat offal with untreated citrus pulp in broiler chick diet. Tropical Animal
Production 5: 95-100.

Iyayi, E. A. and Davies, B. I. 2005. Effect of enzyme supplementation of palm kernel meal and brewer's dried grains on the performance of broilers. International Journal of poultry science. 4(2): 76 - 80 .

Janessen, W. M. and Carve, B. 1995. Influence of fibre on digestibility of poultry feeds. In: Haresign, W., Cole. D.J.A. (Eds.) recent Advances in Animal Nutrition Butter Worths London, pp. 71-86.

Lawal, T. E., Ademola, S. G., Owoseni, A., Atobatele, O. E. and Oriye, L. $O$. 2013. Use of Aspergillus niger for improving the feeding value of rice offal. African Journal of Biotechnology. 12(20): 3083-3087.

Lawal, M. O., Eniola, O., Amos, A. O., Jattodayo, K. A., Fadimu, B. O. and Babatunde, R. O. 2017. Performance characteristics of broiler chickens fed diets supplemented with yam peel (Dioscorea cayanensis) as a partial replacement for maize. Journal of forestry research and management. 14 (1) $49-60$.

Mariscal-Landin, G., Avellaneda, J. H., Reis de Souza, T. C., Aguilera, A., Borbolla, G. A. and Mar, B. 2004. Effect of tannin in sorghum on amino acid ileal digestibility and on trypsin and chymotrypsin activity of growing pigs. Animal Feed Science and Technology 117: 245264.

Meng, X. and Slominski, B. A. 2005. Nutritive values of Corn, Soya bean Meal, Canola meal peas for broiler chickens as affected by a multi carbohydrate preparation of cell wall degrading enzymes. Journal of poultry science. 84: 12-42.

N.R.C. 1994. Nutritional Research Council 


\section{Evaluation of maize-yam peel meal based diets}

Nutrient Requirement of poultry $9^{\text {th }}$ edn. Revised edition National Academy of Science. Washington D.C.

Oduguwa, O. O., Pirgozliev, V. and Acamovic, T. 2007. Energy metabolizability and digestibility of amino acids by broilers fed on malted sorghum sprouts supplemented with polyethylene glycol, charcoal, phytase and xylanase. British Poultry Science. 48: 55-63.

Ojewola, G. S., Okpara, O. E. and Ndupu, O. 1999. The substation value of cassava meals s u p p l e m e n t e d a n d unsupplemented with palm oil for maize in broiler diet. Journal. Animal. Veterinary. Adv. 5 (6): 478482.

Olukosi, O. A., Beeson, L. A., Englyst, K. and Romero, L. F. 2015. Effects of exogenous proteases without or with carbohydrates on nutrient digestibility and disappearance of non-starch polysaccharides in broiler chickens. Journal of Poultry Science. 94: 2662-2669.

Oruseibio, S. M. and Smile, G. O. 2002. Evaluation of palm kernel cake in replacing soya bean meal as a protein source in broiler chickens production. In: Proc. of 6th Annual Conference of Animal Science Association of Nigeria, Sept., 1719.

Rotter, B. A., Friesen, O. D., Guenter, W. and Marguard, R. R. 1990. Influence of enzyme supplementation on the bioavailability energy of barley. Poultry science. 69: 1174-1181.
Sibbald, I. R. 1989. Metabolizable energy evaluation of poultry diets. In: Cole, D.J.A., Haresign, W. (Eds.), Recent Developments in Poultry Nutrition. Ancho Press Ltd.

Soltan, M. A. 2009. Growth performance, immune response and carcass traits of broiler chicks fed on graded levels of palm kernel cake without or with enzymes supplementation. Livestock research for rural development 21:1-15.

SPSS 2012. Statistical package for social sciences, version 21. USA IBM Corporation.

Tewe, O. O., Aderemi, F. A. and Oguntimehin, G. B. 1987. Processing and utilization of cassava roots in diets for layers IITA tropical root sand tuber crops. Bulletin 9 (2), 9-12.

Vioveros, A., Centeno, C., Brenes, A., Canales, R. and Lozana, A. 2000. Phytase and phosphatase activities in plant feed stuffs. Journal of Agricultural and food chemistry. 48: 4009-4013.

Yunusa, Y., Doma, U. D., Zahraddeen, D., Umar, A. and Abubakar, S. B. 2014 . Carcass and gut characteristics of broiler chicken fed Different Energy Source. International Journal of poultry science 13(9): 525-529.

Received: $3^{\text {rd }}$ September, 2018 Accepted: $21^{\text {st }}$ December, 2018 